\title{
INTRODUCTION
}

\section{Exploring Violence(s) in the History of Education}

\author{
Björn Norlin
}

This special issue addresses the broad theme of education and violence. Its overall aim is to contribute to the understanding of different forms, roles, and meanings of symbolic and physical violence and their significance for past educational practices, and at the same time to give theoretical, methodological, and empirical impetus for future studies in this area. By expanding on the concept, or meta-concept, of violence rather than on more common and restricted terms in educational history research such as discipline, punishment, etcetera, the ambition is that this issue will work as a support for a renewed and broadened dialogue of what might or might not be considered as violence in past educational contexts.

The following pages of this introduction focus on the phenomenon and concept of violence and position it within educational and educational history research. In doing this, specific attention is paid to common matters of interest expressed throughout the issue. Finally, the benefits of an expanded understanding of physical and non-physical expressions of violence in educational history research are discussed, as well as how the concept of violence might be helpful in such a broadening. However, a presentation will first be given of the individual articles in the issue. Because they speak for themselves, the presentation will be kept brief.

\section{The contributions, their scopes, and their empirical sources}

The six contributions in this issue are chronologically ordered and offer examinations of a range of topics from Nordic and trans-Nordic contexts. The first article, co-authored by Øystein Skundberg and Harald Thuen, concerns the political and educational debate on the use of corporal punishment in Norwegian schools-and homes - in the late nineteenth and early twentieth centuries and how this debate is connected to historically deep-rooted pedagogical and philosophical traditions conveying very different attitudes regarding the nature of the child and the role of physical chastisement in children's upbringing. ${ }^{1}$ In the second article, David Sjögren

This special issue has been compiled with the help of research funding from Umeå School of Education, Umeå University.

1 Øystein Skundberg and Harald Thuen, “I kjærlighedens tjeneste': Straffens legitimitet i oppdragelse og undervisning," Nordic Journal of Educational History (Special Issue: Education and Violence) 5 , no. 2 (2018).

Björn Norlin is Associate Professor of History and Education at the Department of Historical, Philosophical, and Religious Studies, Umeå University, Sweden.

Email:bjorn.norlin@umu.se 
examines formal instructions for corrective practises in the bylaws of the emerging and gradually standardised mass schooling of mid and late nineteenth-century Sweden. He uses his findings to argue for the need of methodological improvements for attaining more systematic knowledge on this specific area of educational practice. ${ }^{2}$ The third article is co-authored by Karoliina Puranen and Matti Roitto. It examines the prohibition-but continued use-of corporal punishment in Finnish schools in the 1870s and onwards and highlights how discrepancies between formal legislation and day-to-day school practice can be detected by paralleling different sets of sources. ${ }^{3}$ The fourth article by Björn Lundberg revolves around the enactment of corporal punishment as entertainment at a Swedish Boy Scout camp in 1950 and how this single event came to trigger a public debate targeting and questioning the moral basis of the Swedish scout movement and its perceptions of citizenship. ${ }^{4}$ The fifth article, authored by Jonas Qvarsebo, examines the debate on education and on the conduct of school pupils in Swedish teacher journals between 1946 and 1962-the formative years of the nation's comprehensive schools - and gives an account of the central discourses on behaviour and discipline that were activated in this debate. ${ }^{5}$ The sixth and final article is co-authored by Cecilie Boge and Anna Larsson. It focuses on the introduction and scientification of the concept of bullying in the management of violence between pupils in Sweden and Norway during the 1970s, 1980s, and 1990s and how theoretical tools from the field of the history of science and technology can be used to better define the entanglement of actors, practises, and underlying interests involved in this process. ${ }^{6}$

The individual articles in the issue thus analyse expressions of violence on many different levels and within many different practices of the educational domain, including the discourses and debates, law and research as well as in the intramural practises of schooling. The main emphasis of the articles tends to be on various physical facets of violence, although this somewhat restrictive perception is continuously nuanced and problematised. The sources used in the articles include normative records such as formal legislation, school instructions and bylaws; professional and public sources in the form of academic research, teacher journals, handbooks and manuals for children's upbringing, scouting magazines, and newspaper articles; and data more closely linked to knowledge about everyday school life such as punishment records, school minutes, and log books. All in all, they provide the reader with a useful palette of potential topics of research as well as data to consider for future studies in this area.

2 David Sjögren, "Kärleksfullt tilltal, kvarsittning eller kroppsaga: En modellgenererande undersökning om korrektionsmedel i 1800-talets folkskolereglementen," Nordic Journal of Educational History (Special Issue: Education and Violence) 5, no. 2 (2018).

3 Karoliina Puranen and Matti Roitto, "Gradual Changes to Discipline: A Case Study of Punishment Records and Corporal Punishment in Three Schools in Finland after the 1872 School Order Act," Nordic Journal of Educational History (Special Issue: Education and Violence) 5, no. 2 (2018).

4 Björn Lundberg, "Discipline and Punish at Camp: Citizenship and the Issue of Violence at a Swedish Boy Scout Camp," Nordic Journal of Educational History (Special Issue: Education and Violence) 5, no. 2 (2018).

5 Jonas Qvarsebo, "Fabricating and Governing the Swedish School Pupil: The Swedish Post-War School Reform and Changing Discourses of Discipline and Behaviour," Nordic Journal of Educational History (Special Issue: Education and Violence) 5, no. 2 (2018).

6 Cecilie Boge and Anna Larsson, "Understanding Pupil Violence: Bullying Theory as Technoscience in Sweden and Norway," Nordic Journal of Educational History (Special Issue: Education and Violence) 5 , no. 2 (2018). 


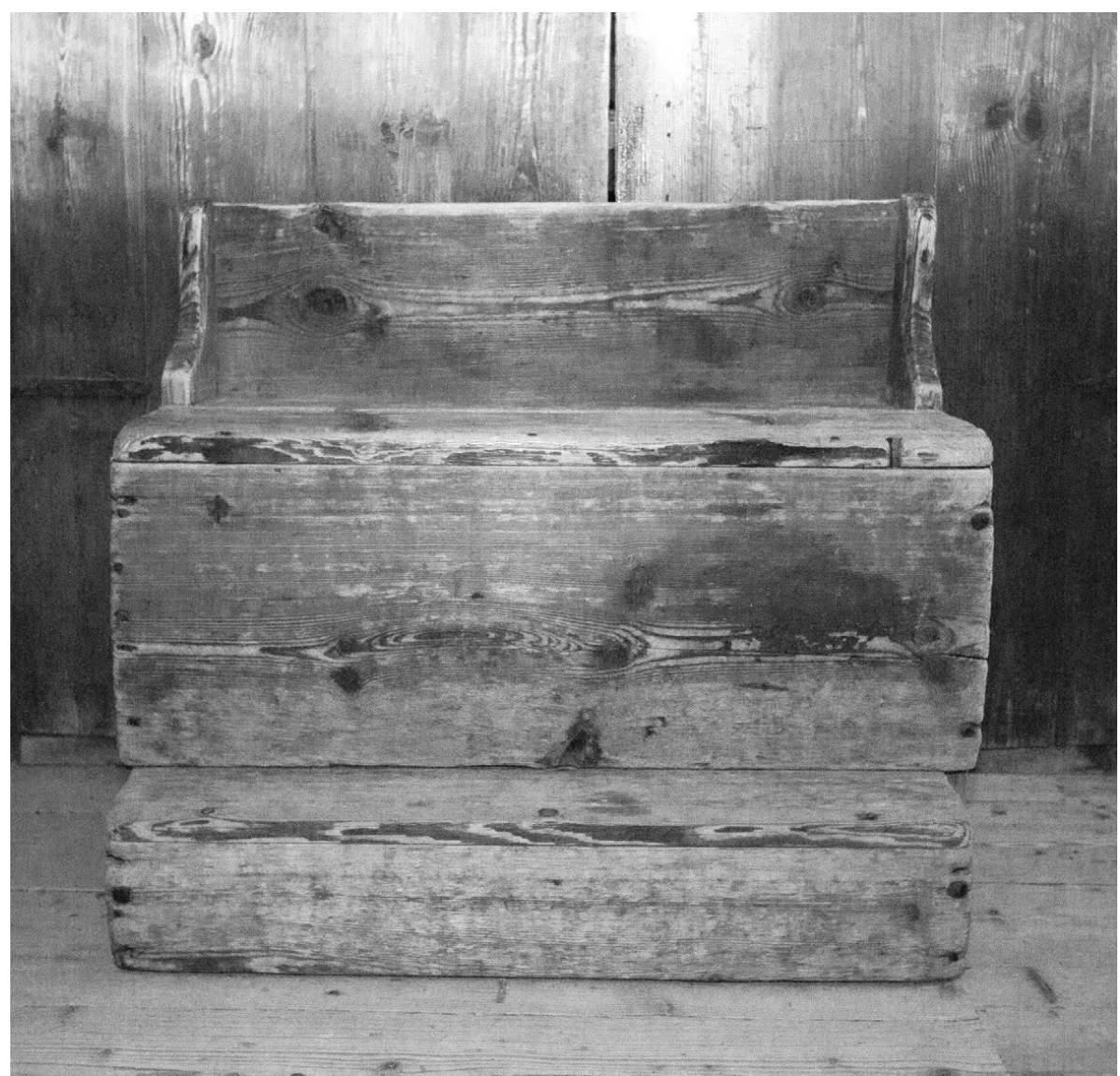

Figure 1 (Cover photo). The Shame Stool (skampall). An iconic piece of early modern teaching technology in the important area of moral education, and a very hands-on material example of the school's mandate to use symbolic and physical measures in the upbringing of children. Its purpose was to evoke and put shame on display, but also to work as a warning to pupils to stay on the right moral tracks. By this, future misconduct was to be prevented. Is instilling shame in children to be seen as violence? Is it even a physical act? These are questions that-among other things — are addressed in the introduction of this issue.

Source: Digitalt museum, SKANM.0134265.

\section{Conceptions of violence(s) and its presence in contemporary society and education}

How can one grab hold of something as elusive and epistemologically fluid as violence? Let us start with a contemporary lexical approach. A standard definition of violence from the Oxford dictionaries gives three parallel explanations: "Behaviour involving physical force intended to hurt, damage, or kill someone or something;" "The unlawful exercise of physical force or intimidation by the exhibition of such force" (Law), and "Strength of emotion or of a destructive natural force."7 Understandably, scientific research is rarely so encyclopaedic, let alone consensus-bound,

7 https://en.oxforddictionaries.com/definition/violence. 
in handling its analytical objects. ${ }^{8}$ In previous efforts to study and theorise violence, violence, whether handled on a conceptual level or dealt with as an experienced social phenomena, is instead considered to be highly complex and multifaceted. ${ }^{9}$ In contemporary society we regularly meet acts of what can be perceived as violence stretching from warfare and war-related atrocities, to structural mistreatments of collective groups, to single acts of abuse by or between individuals. It is embedded in our society, culture, and everyday life in the doings of governmental agencies (most obvious the military and the police), institutions (like the school), and in the acts of other social agents such as families, peer groups, intimate relationships, and in persons' treatment of themselves and others. It is present in the public sphere in the form of museums and collective memorial places (exhibiting military triumphs and war traumas), in sports, as well as in the media and entertainment industry's frequent visualisation of violence for information or entertainment purposes. Experiences of violence are instilled in, and for some also imprinted on, our bodies. In other words, to use a quote from Jane Kilby, when addressing the challenges in theorising on the concept from a sociologist perspective, violence stands as "a complex reality" in the sense that it is both "material and symbolic; structural and aberrant; collective and individual; visible and invisible; legal, extralegal and illegal; brutal and subtle; sporadic and everyday; and spectacular and banal." ${ }^{10}$ Violence emanates from many different contexts and thus exists in many different forms.

Taking this into account, it is not surprising that the definition of what violence is might also vary greatly between different scientific fields (military science, peace studies, criminology, law, sociology, philosophy, pedagogy, history, etcetera), different subareas of research, and among individual scholars regardless of their disciplinary domicile. While some researchers aim to define and clarify an understanding of what violence is from its very condensed meaning of a single act of intentional cause of physical harm between individuals, and to examine the concept from this point of departure, others look for a more structural and context-bound understanding and by this enact violence as a more subtle, non-visible, and non-physical phenomenon. ${ }^{11}$

In contemporary educational debate and educational research, the presence of violence in schools in its various and wide range of forms - from the most extreme such as school shootings and other lethal assaults, gang violence, suicides, self-injuries, and sexual harassment, to teachers mistreatments of pupils, battering and bullying in day-to-day school life, and so on-is something that is frequently addressed as an important field of responsibility for schools that needs to be handled. This could, for instance, be by preventing alienation and countercultures among school

8 The lexical meaning of violence is of course also subjected to historical change, which is an element in need of consideration for historical studies. Cf. the discussion on the historical meaning of the Swedish concept of aga in Sjögren (2018).

9 For in-depth discussions on the concept of violence and its individual, cultural, discursive and structural dimensions, see e.g. Johan Galtung, "Violence, Peace, and Peace Research," Journal of Peace Research 6, no. 3 (1969), 167-91; Johan Galtung, "Cultural Violence," Journal of Peace Research 27, no. 3 (1990), 291-305; Ryan Bishop and John Phillips, "Violence," Theory, Culture \& Society 23, no. 2-3 (2006), 377-85; Jane Kilby, "Introduction to Special Issue: Theorizing Violence," European Journal of Social Theory 16, no. 3 (2013), 261-72.

10 Kilby (2013), 261-72.

11 Ibid. 
youth, strengthening surveillance, discipline, and control in schools, supporting inter-professional cooperation and collaboration with parents and guardians, changing legislation, or assisting in the general work with ethical and social values at the local school level-in other words, acting on and altering the social and structural conditions that provide the contextual frames within which violence subsists. ${ }^{12}$ In the present issue, Cecilie Boge and Anna Larsson, in particular, touch upon these kinds of matters in a very contemporary history. ${ }^{13}$

It is notable that this strand of contemporary research is primarily focusing on an area of education that differs quite significantly from research in the history of education in the sense that it is no longer the role of violence as an officially sanctioned element of governing schools, or as a part of common teaching practice, that is emphasised, but rather its various expressions in the social life of schooling.

\section{A brief historiography of violence in past education}

In sociological, pedagogical, and historical research-familiar to many historians of education-issues relating to the understanding of violence as a phenomenon in educational contexts has a lengthy historiography. This body of research includes both empirical studies of the role of violence in school practice and more manifested efforts of theorising on such violence. An early example is provided by historian Hastings Rashdall who in his studies of medieval European universities and secondary schools, published in 1895, highlighted elements such as violent initiation rituals and various other disciplinary practices as central parts of intramural life in regards to both the social relations between students and the general efforts of organising teaching. ${ }^{14}$ His work has since been used as an empirical backdrop for analysing and theorising on disciplinary practice in education. ${ }^{15}$

In Émile Durkheim's investigations of different aspects of violence in his contemporary society (suicide, violence and the state, family, etcetera), adding pieces to what by some can be understood as a general theory of violence and its causes, he

12 Cf. Ingrid Rose, School Violence: Studies in Alienation, Revenge, and Redemption (London: Karnac Books, 2009); Mohammad Shafii and Sharon Lee Shafii, eds., School Violence: Assessment, Management, Prevention (Washington DC: American Psychiatric Press, 2001). To use Sweden as an example there are today plenty of government reports and research drawing attention to different aspects of violence in schools and, accordingly, different measures have been proposed to handle them. A common denominator is the link between potential violence and value-based prevention work in schools. Cf. Felipe Estrada, Sven Granath, David Shannon and Nina Törnqvist (red.), Grövre våld i skolan (Stockholm: Brottsförebyggande rådet, 2009). In 2015 the governmental agency Barnombudsmannen (the Children's Ombudsman) launched a package of demands to strengthen children's legal status in relation to teachers, including a proposal to reintroduce the ban on corporal punishment in the school law (this legal clarification was removed in 1986 because it was no longer deemed necessary). The background for Barnombudsmannen's proposal was a survey that revealed a widespread occurrence of physical violations between teachers and pupils in Swedish schools, which obviously did not fit with the Swedish school's professed values and self-image. Välkommen till verkligheten: Barn och unga om samhällets stöd vid kränkningar och trakasserier $i$ skolan (Stockholm: Barnombudsmannen, 2015).

13 Boge and Larsson (2018).

14 Hastings Rashdall, The Universities of Europe in the Middle Ages (Oxford: Oxford University Press, 1997), vol. III, Chapter XIV, 376-85, 419-39. For more contemporary research on a similar topic, see Alan Cobban, English University Life in the Middle Ages (London: UCL Press, 1999), 198-211.

15 Cf. Philippe Ariés, Centuries of Childhood: A Social History of Family Life (New York: Vintage Books, 1962), 157, 259. 
also gives education and pedagogical practises a central positioning. ${ }^{16}$ An evident example is his published lectures on moral education, held between 1902 and 1907, in which he in detail elaborates on "the spirit of discipline" in schools, the role of physical and non-physical punishment in pedagogy and teaching practice, as well as on the relation between corrective practices, psychology, and institutionalised group norms. ${ }^{17} \mathrm{He}$ also gives accounts for disciplinary violence in past school settings, and in a couple of texts he suggests paradigmatic shifts within the educational domain in this area from the Middle Ages onwards. ${ }^{18}$

Norbert Elias's work on the process of civilisation in many ways connects to Durkheim's thoughts about long-term paradigmatic shifts in mentality as a base for theorising about violence, and this is perhaps most evident in his sections about changes in aggressiveness and aggressive behaviour and impulses as well as the general attitudes to war, torture, violent games, etcetera. He argues that different societies - and even different social strata within societies - both in history and in his contemporary time impose different social structures and control mechanisms for handling aggressive behaviour and expressions of violence. These structures and mechanisms are in turn subjected to historical change, which thus presupposes that violence must be understood and examined as a historically situated phenomenon. ${ }^{19}$ Following Max Weber, he also elaborates on the role of violence within state-formation processes and on its vital position for state governance and use of power; that is, the monopoly mechanism. ${ }^{20}$

These theoretical approaches to violence might give impetus for research aiming at understanding the specific role of education in the broader landscape of state-governed and institutionalised violence, as well as in sorting out the historical relation between, for instance, the state, church, town administration, school, and home as separate socio-institutional contexts with their own jurisdictions and mandates to use violence.

16 International Social Science Journal (Special Issue: Durkheim and Violence) 58 (2006), passim; In particular Mike Gane "Durkheim's Theory of Violence," International Social Science Journal 58 (2006), 41-50.

17 Émile Durkheim, Moral Education: A Study in the Theory and Application of the Sociology of Education (New York: Free Press, 1973), in particular chapters 10-13.

18 Émile Durkheim, The Evolution of Educational Thought: Lectures on the Formation and Development of Secondary Education in France (London: Routledge and Kegan, 1977), chapter 13; Gane (2006), $41-50$.

19 Norbert Elias, The Civilizing Process [Vol. 1]: The History of Manners (Oxford: Blackwell, 1978), 191-205.

20 Norbert Elias, On Civilization, Power, and Knowledge: Selected Writings (Chicago: University of Chicago Press, 1998), chapter 8-9. Elias is drawing on Max Weber's Economy and Society: An Outline of Interpretive Sociology [Vol. 1] (New York: Bedminster P., 1968). 


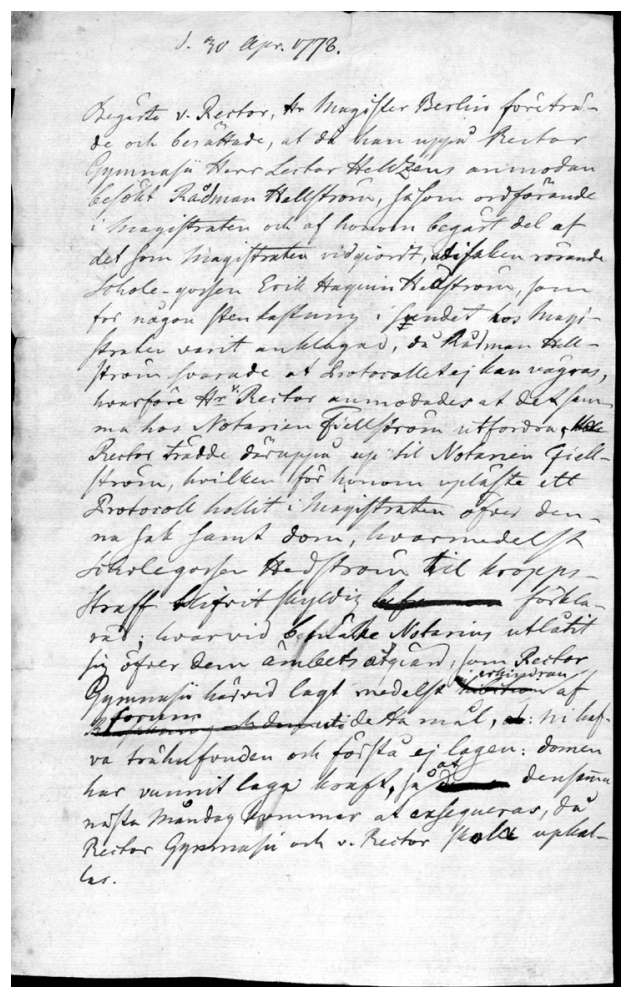

Figure 2. Negotiating the institutional mandate of violence. A (draft) letter from the upper secondary school in the Swedish town of Härnösand from 1778 describing a conflict between the town court and the school regarding the right to punish pupils. Its origin was that a schoolboy, after an alleged stone throwing incident in the harbour, had been called before the town court and subsequently sentenced to physical punishment. This started an infected exchange of words between the school and town representatives concerning the mandate to use violence against pupils. "You have wooden heads (trähufvuden) and do not understand the law" was, among other things, stated by the notary of the Magistrate. This small affair can be seen as an example of a larger conflict between two parallel existing juridical systems and indirectly of the relationship between the school (state/church) and the city (magistrate) in exercising power.

Source: Handskrift (30/4 1778), Domkapitlets arkiv G1, Handlingar angående undervisning och skolväsen/läroverken i allmänhet (GIa), Landsarkivet i Härnösand.

In his writings on the history of childhood and family life, Phillippe Ariés also addresses various elements of violence and disciplinary measures as a part of educational governance and practice. Similar to Durkheim, Ariés defines what he sees as the emergence of new disciplinary doctrines in schools and universities-affecting the social relations between students as well as those between student and teachers-in particular from the sixteenth and seventeenth centuries and onwards. According to Ariés, this period saw a gradual domestication of what had previously been an autonomous student life, a domestication that accompanied more general administrative efforts to standardise schooling. This process was characterised by the introduction of more hierarchical ways of governing schools, a strengthened authoritarian role of the school masters, and the appearance of more fixed views of childhood as something that needed to be governed. The transition to this new disciplinary system was based on three new educational principles, namely, "constant supervision," the advance of the art of informing to "the level of an institution and a principle of government," and "the extended application of corporal punishment." ${ }^{21}$ Ariés also elaborates on the introduction of new strategies and technologies for upholding discipline and for exercising punishment in schools and how this connects to new ways of perceiving childhood. ${ }^{22}$

Ariés can be seen as having paved the way for the later works on discipline and punishment of Michel Foucault, although the latter develops them and applies them

21 Ariés (1962), 254-264. Quote from p. 254.

22 Ibid., chapter $\mathrm{V}$ in particular. 
to a wider societal context. ${ }^{23}$ Foucault obviously holds a central position in contemporary research focused on these areas of education and educational governance. With his theories of how different governmental modes of power makes use of different forms of violence and discipline, the long-term transitions of mentalities regarding forms of punishment and techniques for governing, as well as the significance of organising space, time, and social routine in these processes, he provides an extensive theoretical toolbox for research in this area. Education-as an experimental training ground for discipline in western societies - is often the focal point. ${ }^{24}$ Foucault's vital position as a point of departure for the analysis, and as a target for criticism, is also manifest in this present issue in the articles by Qvarsebo, Lundberg, and Puranen and Roitto. ${ }^{25}$

Finally, Pierre Bourdieu's theories about symbolic power and symbolic violence, developed further by various scholars to match different social contexts-such as gender relations, marginalised groups in relation to societal norms, etcetera-offers yet another analytical backdrop for understanding violence with a more marked focus on its non-physical elements and its entanglement in different power relations as well as social and cultural norms. Even if Bourdieu's theories are developed on a quite non-figurative level of education (all formal schooling as cultural/symbolic violence embedded and masked in pedagogy), they also appear to supply a link between the individual and the social context and an opening to incorporate the significance of gender, body, and emotions in exploring violence on a micro level. ${ }^{26}$

What connects many of these efforts of understanding and theorising violence in different times and contexts is that they tend to draw our focus from violence as specific idiosyncratic manifestations of human existence towards their causes, hidden and seemingly natural conditions, and discourses. By this they also blur the lines between individual and social context and between violence as a particular act and the objective circumstances, processes, and practices it is embedded in. This relational approach to violence also presupposes an historical understanding, that is, knowledge about the historical processes and ever-changing environments in which violence exists and gains its meaning. However, regarding education they primarily locate violence as a part of formal school practice and governance, which gives them a somewhat restricted scope, limiting the understanding of, for example, violence that exists outside the direct formal educational sphere (in extracurricular life, in social relations between students, etcetera).

23 See discussion in Jeroen J.H. Dekker, Bernard Kruithof, Frank Simon and Bruno Vanobbergen, "Discoveries of Childhood in History: An Introduction," Paedagogica Historica 48, no. 1 (2012), $1-9$.

24 Michel Foucault, "Governmentality," in The Foucault Effect: Studies in Governmentality, ed. Graham Burchell, Colin Gordon and Peter Miller (Chicago: Chicago University Press, 1991); Michel Foucault, Discipline and Punish: The Birth of the Prison (London: Peregrine Books, 1982), especially part III.

25 See Lundberg (2018); Qvarsebo (2018); Puranen and Roitto (2018).

26 Pierre Bourdieu and Jean-Claude Passeron, Reproduction in Education, Society and Culture (Book 1: Foundations of a Theory of Symbolic Violence) [2. ed.] (London: Sage, 1990); Pierre Bourdieu, Language and Symbolic Power (Cambridge, MA: Harvard University Press, 1991); C. Samuel, "Symbolic Violence and Collective Identity: Pierre Bourdieu and the Ethics of Resistance," Social Movement Studies 12, no. 4 (2013), 397-413; Monique Scheer, "Are Emotions a Kind of Practice (and Is That What Makes Them Have a History)? A Bourdieuian Approach to Understanding Emotion," History and Theory 51, no. 2 (2012), 193-220. 
There is obviously a body of more recent research on the present area, and the individual articles in this issue provide plenty of updated discussions on the state of the art. $^{27}$

\section{On physical and non-physical violence}

Discussions about the role of physical violence in past education recurrently appear in this issue. Skundberg and Thuen address the use of corporal punishment and its relation to the general views of the nature of the child as expressed in different pedagogical traditions - including pietism, John Locke's rationalism, Jean-Jacques Rousseau's naturalistic philosophy, Herbert Spencer's naturalism, and social Darwinism. ${ }^{28}$ Sjögren goes into schematic detail on the relation between corporal punishment and various other forms of correction in Swedish nineteenth century mass schooling, exposing a range of systematised disciplinary means stretching from mild and tenderly telling-offs to strict physical chastisement, ${ }^{29}$ and Puranen and Roitto criticise what they see as anachronistic understandings of corporal punishment in previous research. ${ }^{30}$

Indirectly, this touches upon interesting analytical questions about what physical-and non-physical-violence actually is in the contexts that we are studying. Against the background of what has been discussed in this introduction, corporal punishment can on the one hand be seen as a quite peripheral part of violence in education. On the other hand, the act of physical punishment always appears to have had a distinct position within pedagogical and educational thinking. To cross the line from the solely symbolic, or at least the seemingly non-physical, such as telling-offs, warnings, blaming, pecuniary fines, expulsion, and other types of correctives meant to have social and/or emotional impact, to the corporal in exercising discipline over children seems to have required explicit argumentation as to the reasons for why this should happen. Ariés spends pages writing about how the act of physical chastisement grew to become the most prominent form of scholastic punishment during

27 Cf. Alan Cumming, "Discipline: An Historical Overview," Paedagogica Historica 9, no. 1-2 (1969); Llyod de Mause, ed., The History of Childhood: The Untold Story of Child Abuse (London: Bellow, 1991); Bruce Curtis, “My Ladie Birchely must needes rule:' Punishment and Materialization of Moral Character from Mulcaster to Lancaster," in Discipline, Moral Regulation, and Schooling: A Social History, ed. Kate Rousmaniere, Kari Dehli and Ning de Coninck-Smith (New York: Garland Publishing, 1997); Ning de Coninck-Smith, "A History of School Detention, or "The Little Confinement:' A Contribution to the History of Truancy in Denmark from 1875 to ca. 1914," in Discipline, Moral Regulation, and Schooling: A Social History, ed. Kate Rousmaniere, Kari Dehli and Ning de Coninck-Smith (New York: Garland Publishing, 1997); Eric Margolis and Sheila Fram, "Caught Napping: Images of Surveillance, Discipline and Punishment on the Body of the Schoolchild," History of Education 36, no. 2 (2007), 191-211; Frederik Herman, et al., "Punishment as an Educational Technology: A Form of Pedagogical Inertia in Schools?” Educational Research: Networks and Technologies 2 (2007), 203-19; Jacob Middleton, “The Experience of Corporal Punishment in Schools, 1890-1940," History of Education 37, no. 2 (2008), 253-75; Matthew Pate and Laurie A. Gould, Corporal Punishment Around the World (Oxford: Praeger, 2012); Carles Sirera Miralles, "Enlightened Paternalism: The Prohibition of Corporal Punishment in Spanish Public Schools in the Nineteenth Century," History of Education 44, no. 2 (2015), 156-70; Björn Norlin, "School Jailhouse: Discipline, Space and the Materiality of School Morale in Early-Modern Sweden," History of Education 45, no. 3, (2016), 263-84.

28 Skundberg and Thuen (2018).

29 Sjögren (2018).

30 Puranen and Roitto (2018). 
the sixteenth century, replacing, for example, pecuniary penance that had previously been very common. ${ }^{31}$ Early modern theologians, pedagogical philosophers, and school reformers such as Desiderius Erasmus expressed elaborate thoughts on the use of physical punishment in children's upbringing (giving restrictive guidelines to parents and schoolmasters regarding such punishment), ${ }^{32}$ and John Amos Comenius wrote extensively on the matter in his great didactics. Comenius did not at all reject corporal punishment, especially not when it came to abnormal children, but he saw it as a very last resort for corrective practise and in all cases as a sign of inadequately organised teaching. Instead, he advocated various other techniques for upholding discipline without having to become physical with children, such as strategic use of blame and ridiculing in the classroom, enforcing internal competition among children, and establishing hierarchical systems for control and surveillance in schools, that is preventive rather than repressive actions. ${ }^{33}$

In any case, physical expressions of violence seem to hold a distinguished position both in past educational thinking and practice and in educational history research. However, a question is whether too tight a focus on the physical limits our possibilities to discover other ways of perceiving acts of violence and to analytically handle the corporal in relation to seemingly symbolic and non-corporal forms of punishment. It is fairly easy to grasp that the early modern use of hands, birch rods, ferules, switches, foot blocks, and pillories to get pupils back on the morally right track are physically violent acts, but what about other common and parallel forms of penance such as incarceration, social isolation, public admonitions and humiliations, as well as the various forms of measures to evoke hunger, fear, anxiety, shame, stress, and ignominy in children - in other words, emotions with highly negative psychological and physiological impacts? Are mere threats of using physical force or instilling the fear of God in children in fact physical acts? Are structural surveillance, measuring, and enforcing competition among children for pedagogical purposes acts of violence? Can even fatherly and tender admonitions be seen as such considering their institutional framing? In other words, what differentiates physical violence from non-physical violence, and what is the common denominator?

This might seem like splitting hairs, but it is nonetheless relevant for how we perceive expressions of violence in past school contexts and how we theorise them and locate them in different dimensions and practices of education. In the end, the concept of violence is not to be found in history per se, but in the heads and analyses of researchers.

\footnotetext{
31 Ariés (1962), 257.
}

32 Cf. William Harrison Woodward, Desiderius Erasmus Concerning the Aim and Method of Education (Cambridge: Cambridge University Press, 1904), 91-95. See also Charlotte Appel and Morten Fink-Jensen, Da loereren holdt skole: Tiden før 1780 [Dansk skolehistorie, band 1] (Aarhus: Aarhus Universitetsforlag, 2013), chapter 4.

33 The Great Didactics of John Amos Comenius (London, A. and C. Black, 1896), chapters 23, 24 and 26; Björn Norlin, "Comenius, the Great Didactics, and its Influence on the area of School Discipline in Seventeenth Century Sweden," paper presented at the session New Perspectives on School Discipline at the European Social Science History Conference (ESSHC), Belfast, April 4-7, 2018. 


\section{Concluding remarks: The potentials of a renewed dialogue on violence in educational history}

So, what to make of all this? It appears evident that expressions of what can be perceived as violence-including the discursive and institutional level of education, teaching practice, and the social life of everyday schooling-hold a significant place in the history of education. It also seems accurate to claim that there still is plenty left to explore in this area and that such an exploration holds the potential of both broadening and deepening our knowledge of a very important dimension of the educational heritage of the Nordic, European and Western context. Such knowledge would most likely also work as support for a better understanding of the place of violence in contemporary schooling. It also appears accurate to claim that the field of educational history, unlike many other research fields, today is lacking an initiated dialogue on violence of empirical as well as of theoretical nature.

If this is the case, how do we move forward and how can the concept of violence support this process? Kilby addresses a few things that might be helpful to have in mind also for a renewed and expanded dialogue on the area within the history of education. Firstly, which probably has been made clear, she emphasises that violence must be handled as a meta-concept and as subjected to multiple understandings, as violences rather than violence. Acknowledging this variation in perceiving and handling violence can be seen as crucial for all research entering the area and as a precondition for a fruitful analytical dialogue. This elasticity might certainly cause some problems, but it also comes with the potential to support a multidimensional and far-reaching exploration of the area in question. Secondly, she proposes a shift in research focus from paying prime attention to subjective forms and physical acts of violence to also incorporating the seemingly neutral circumstances and practices that allow for their existence. Only when individual acts of violence are analysed in relation to the more taken for granted conditions, environments, and practices they are embedded in, can an ampler understanding be achieved. Thirdly, which is related to the second, is that research on violence not only often has the individual act of violence in prime focus, but also its perpetrators rather than its victims and its consequences. This means that important parts of the magnitude of violence often fall outside of the scope of research. The delicate issue is thus to see beyond individual acts of violence while still attend to subjective experiences of it. ${ }^{34}$

For educational historians, researching violence inevitably means "limiting" the scope of it to education, that is, recognising that manifestations of violence in formal legislation, policy, public debate, everyday pedagogical and social school practice, and so on are bound to a specific socio-institutional framing — the school-which at least partly separates them from those of other institutions and social contexts. Violence in education is to a large extent coloured and defined by its own institutional logic and sociality, as well as by its formal collective principles. This is evidently not the same as to claim that education and schooling are freestanding and isolated domains. On the contrary, as has just been discussed, schooling might be best understood in relation to the practice of other institutions and social contexts such as the home, the church, the peer group, etcetera, and to more general societal conditions such as law and legislation as well as to political and professional debates.

34 Kilby (2013), 261-72. 
Moving from an institutional level of understanding violence to its more concrete and adjusted role in pedagogical thinking and practise, this appears to be clearly linked to and defined by how children and childhood in general have been perceived - that is, what it in different times and pedagogical circumstances has meant to be a child. However, it is also important here to recognise that we are often dealing with institutionalised childhood, more specifically, what it means to be a pupil or disciple. The child and the pupil are not necessarily the same constructs.

Furthermore, educational historians appear to follow along the same line as indicated by Kilby regarding the general focus of research in the field. The attention is often top down, on violence as a formal element in governing schools and as a part of pedagogical thinking and practice and on agents such as the headmaster, teacher, parent, or the institution itself. These are the acting subjects of violence. What would happen if the scope of future research also turned towards the victims of violence and its consequences for those that were subjected to it, or towards its manifestations in the multifarious, more unregulated, and therefore also more invisible social life of schooling (as the focus appears to be in educational research nowadays)?

The keys to support such new research trajectories in the area-from focusing on subjective acts of violence and their perpetrators towards their institutional and social conditions as well as their victims and consequences-perhaps lie in paying better analytical attention to non-physical forms of violence (instead of its corporal eruptions), the relation between the use of violence and specific knowledge areas (such as the socio-moral), its ideological foundations (often the classical and religious virtues), its impact on educational space and materiality (spatial reconfigurations and the advance of teaching technologies in managing the use of violence in schools), individual experiences of school violence (in memories, autobiographies, etcetera), its "hidden" manifestations in the social life of schooling and the relations between pupils, the role of emotions and emotional regimes in understanding punishment practice in schools, and perhaps also by putting perceptions of the bodythe nexus of physical and symbolical violence-in the centre of research. Such trajectories would not only presuppose different research perspectives, but also new sets of sources.

In any case, if there is an interest for renewing and broadening the scientific dialogue on violence in educational history, the field appears to be a vast, interesting, and important area to explore. In such a process, the concept of violence might work as a common conceptual hub, a joint point of departure for research spreading out in various disciplinary directions. It could be made a concept for continuous problematisation-flexible enough to suit a multidisciplinary field such as that of educational history-and hopefully also work as an aid in discovering new areas for research. A key to a productive research dialogue is conceivably also to actively break down violence into more concrete sub areas-or sub concepts - as well as to clearly define empirical objects of study in order to position them as a part of the broader spectra. It is the editor's hope that this issue can make a contribution to such a future dialogue. 


\section{References}

Appel, Charlotte and Morten Fink-Jensen. Da loereren holdt skole: Tiden før 1780 [Dansk skolehistorie, band 1]. Aarhus: Aarhus Universitetsforlag, 2013.

Ariés, Philippe. Centuries of Childhood: A Social History of Family Life. New York: Vintage Books, 1962.

Bishop, Ryan and John Phillips. "Violence." Theory, Culture \& Society 23, no. 2-3, (2006), 377-85.

Boge, Cecilie and Anna Larsson. "Understanding Pupil Violence: Bullying Theory as Technoscience in Sweden and Norway", Nordic Journal of Educational History (Special Issue: Education and Violence) 5, no. 2 (2018).

Bourdieu, Pierre and Jean-Claude Passeron. Reproduction in Education, Society and Culture (Book 1: Foundations of a Theory of Symbolic Violence) [2. ed.]. London: Sage, 1990.

Bourdieu, Pierre. Language and Symbolic Power. Cambridge, MA: Harvard University Press, 1991.

Cobban, Alan. English University Life in the Middle Ages. London: UCL Press, 1999.

Comenius, John Amos. The Great Didactics of John Amos Comenius. London: A. and C. Black, 1896.

de Coninck-Smith, Ning. "A History of School Detention, or 'The Little Confinement:' A Contribution to the History of Truancy in Denmark from 1875 to ca. 1914." In Discipline, Moral Regulation, and Schooling: A Social History, edited by Kate Rousmaniere, Kari Dehli and Ning de Coninck-Smith. New York: Garland Publishing, 1997.

Cumming, Alan. "Discipline: An Historical Overview." Paedagogica Historica 9, no. $1-2$ (1969).

Curtis, Bruce. 'My Ladie Birchely must needes rule:' Punishment and Materialization of Moral Character from Mulcaster to Lancaster." In Discipline, Moral Regulation, and Schooling: A Social History, edited by Kate Rousmaniere, Kari Dehli and Ning de Coninck-Smith. New York: Garland Publishing, 1997.

Dekker, Jeroen J.H., Bernard Kruithof, Frank Simon and Bruno Vanobbergen. "Discoveries of Childhood in History: An introduction." Paedagogica Historica 48, no. 1 (2012), 1-9.

Durkheim, Émile. Moral Education: A Study in the Theory and Application of the Sociology of Education. New York: Free Press, 1973.

Durkheim, Émile. The Evolution of Educational Thought: Lectures on the Formation and Development of Secondary Education in France. London: Routledge and Kegan, 1977.

Elias, Norbert. The Civilizing Process [Vol. 1]: The History of Manners. Oxford: Blackwell, 1978.

Elias, Norbert. On Civilization, Power, and Knowledge: Selected Writings. Chicago: University of Chicago Press, 1998.

Estrada, Felipe, Sven Granath, David Shannon and Nina Törnqvist eds. Grövre våld $i$ skolan. Stockholm: Brottsförebyggande rådet, 2009.

Foucault, Michel. "Governmentality." In The Foucault Effect: Studies in Governmentality, edited by Graham Burchell, Colin Gordon and Peter Miller. Chicago: Chicago University Press, 1991.

Foucault, Michel. Discipline and Punish: The Birth of the Prison. London: Peregrine Books, 1982. 
Galtung, Johan. "Violence, Peace, and Peace Research." Journal of Peace Research 6, no. 3 (1969), 167-91.

Galtung, Johan. “Cultural Violence.” Journal of Peace Research 27, no. 3 (1990), 291305.

Gane, Mike. "Durkheim's Theory of Violence." International Social Science Journal (Special Issue: Durkheim and Violence) 58 (2006), 41-50.

Harrison Woodward, William. Desiderius Erasmus Concerning the Aim and Method of Education. Cambridge: Cambridge University Press, 1904.

Herman, Frederik, et al., "Punishment as an Educational Technology: A Form of Pedagogical Inertia in Schools?” Educational Research: Networks and Technologies 2 (2007), 203-19.

International Social Science Journal (Special Issue: Durkheim and Violence) 58 (2006).

Kilby, Jane. "Introduction to Special Issue: Theorizing Violence." European Journal of Social Theory 16, no. 3, (2013), 261-72.

Lundberg, Björn. "Discipline and Punish at Camp: Citizenship and the Issue of Violence at a Swedish Boy Scout Camp." Nordic Journal of Educational History (Special Issue: Education and Violence) 5, no. 2 (2018).

Margolis, Eric and Sheila Fram. "Caught Napping: Images of Surveillance, Discipline and Punishment on the Body of the Schoolchild." History of Education 36, no. 2 (2007), 191-211.

de Mause, Llyod, ed. The History of Childhood: The Untold Story of Child Abuse. London: Bellow, 1991.

Middleton, Jacob. “The Experience of Corporal Punishment in Schools, 1890-1940.” History of Education 37, no. 2 (2008), 253-75.

Norlin, Björn. "School Jailhouse: Discipline, Space and the Materiality of School Morale in Early-Modern Sweden." History of Education 45, no. 3 (2016), 263-84.

Norlin, Björn. "Comenius, the Great Didactics, and its Influence on the area of School Discipline in Seventeenth Century Sweden", paper presented at the session New Perspectives on School Discipline at the European Social Science History Conference (ESSHC), Belfast, April 4-7, 2018.

Pate, Matthew and Laurie A. Gould. Corporal Punishment Around the World. Oxford: Praeger, 2012.

Puranen, Karoliina and Matti Roitto. "Gradual Changes to Discipline: A Case Study of Punishment Records and Corporal Punishment in Three Schools in Finland after the 1872 School Order Act." Nordic Journal of Educational History (Special Issue: Education and Violence) 5, no. 2 (2018).

Qvarsebo, Jonas. "Fabricating and Governing the Swedish School Pupil: The Swedish Post-War School Reform and Changing Discourses of Discipline and Behaviour." Nordic Journal of Educational History (Special Issue: Education and Violence) 5, no. 2 (2018).

Rashdall, Hastings. The Universities of Europe in the Middle Ages. Oxford: Oxford University Press, 1997.

Rose, Ingrid. School Violence: Studies in Alienation, Revenge, and Redemption. London: Karnac Books, 2009.

Samuel, Chris. "Symbolic Violence and Collective Identity: Pierre Bourdieu and the Ethics of Resistance." Social Movement Studies 12, no. 4 (2013), 397-413. 
Scheer, Monique. "Are Emotions a Kind of Practice (and Is That What Makes Them Have a History)? A Bourdieuian Approach to Understanding Emotion." History and Theory 51, no. 2 (2012), 193-220.

Shafii, Mohammad and Sharon Lee Shafii, eds. School Violence: Assessment, Management, Prevention. Washington DC: American Psychiatric Press, 2001.

Sirera Miralles, Carles. "Enlightened Paternalism: The Prohibition of Corporal Punishment in Spanish Public Schools in the Nineteenth Century." History of Education 44, no. 2 (2015), 156-70.

Skundberg, Øystein and Harald Thuen. “'I kjærlighedens tjeneste:' Straffens legitimitet i oppdragelse og undervisning." Nordic Journal of Educational History (Special Issue: Education and Violence) 5, no. 2 (2018).

Sjögren, David. "Kärleksfullt tilltal, kvarsittning eller kroppsaga: En modellgenererande undersökning om korrektionsmedel i 1800-talets folkskolereglementen." Nordic Journal of Educational History (Special Issue: Education and Violence) 5, no. 2 (2018).

Weber, Max. Economy and Society: An Outline of Interpretive Sociology [Vol. 1]. New York: Bedminster P., 1968.

Välkommen till verkligheten: Barn och unga om samhällets stöd vid kränkningar och trakasserier i skolan. Stockholm: Barnombudsmannen, 2015. 